\title{
POWER, POLITICS, AND EDUCATION: CANADIAN UNIVERSITIES AND INTERNATIONAL EDUCATION IN AN ERA OF NEW GEOPOLITICS
}

\author{
ROOPA DESAI TRILOKEKAR \\ YORK UNIVERSITY
}

\author{
AMIRA EL MASRI \\ SHERIDAN COLLEGE
}

\author{
HANI EL MASRY \\ SOAS UNIVERSITY OF LONDON
}

\begin{abstract}
This paper focuses on the recent political spars between Canada and Saudi Arabia as well as China and their impact on Canadian universities. It asks three questions: (1) What key issues did Canada's political strains with Saudi Arabia and China raise for Canadian universities' international education (IE) initiatives and what issues were absent? (2) What do these key issues suggest about Canada's approaches to IE in an era of new geopolitics? and (3) What implications can be drawn from these cases about Canadian university-government relations in the context of new geopolitics? Given the powerful role media plays in education policy, a systematic study was conducted across three main media sources to identify 74 articles and news releases between August 2018 and November 2019. Three dominant themes are identified and analyzed, each vividly illustrating the close ties between global politics, government foreign policy and IE within Canadian Universities. On the one hand, the narratives speak to concerns about IE as a risk to national security and, on the other, as a vehicle for Canada's economic prosperity. However, what the media has not achieved is a broader discussion on how Canada needs to revisit its IE objectives and approaches in light of broader geopolitical shifts. Using the theoretical framework of soft power, the paper speaks to the limitations and short-sightedness of Canada's approach to IE as soft power in this era of new geopolitics and concludes with three recommendations for Canada.
\end{abstract}

Keywords: soft power, international education, geopolitics, internationalisation, and international relations

\section{Résumé}

Cet article se concentre sur les répercussions sur les universités canadiennes des tensions politiques récentes entre le Canada et la Chine et entre le Canada et l'Arabie saoudite. II pose trois questions : (1) Quels sont les problèmes causés par ces tensions politiques pour les initiatives d'éducation internationale des universités canadiennes, et quels problèmes sont exclus? (2) Que suggèrent ces problèmes quant aux approches du Canada en ce qui concerne les initiatives d'éducation internationale à l'époque de la nouvelle géopolitique? (3) Quelles sont les implications sur les relations entre les universités canadiennes et le gouvernement du Canada dans le contexte de la nouvelle géopolitique? Puisque les médias jouent un rôle puissant dans les politiques éducatives, nous avons mené une étude systématique auprès de trois sources médiatiques et retenu 74 articles de journaux et communiqués de presse entre août 2018 et novembre 2019. II en ressort trois thèmes principaux qui illustrent les liens étroits entre la politique mondiale, la politique étrangère du gouvernement et les initiatives d'éducation internationale au sein des universités canadiennes. II y a deux narratifs concurrents : d'une part, celui selon lequel l'éducation internationale serait une menace pour la sécurité nationale canadienne et d'autre part, celui selon lequel l'éducation internationale contribuerait à la prospérité économique du Canada. Cependant, les médias n'abordent pas la question plus vaste de la manière dont le Canada devrait revoir ses objectifs et ses approches en matière d'éducation internationale à la lumière des grands changements géopolitiques. L'article utilise le cadre théorique du soft power pour discuter des limitations et du manque de vison de l'approche du Canada en ce qui concerne l'éducation internationale comme soft power à l'époque de la nouvelle géopolitique. La conclusion inclut trois recommandations pour le Canada.

Mots-clés : puissance douce, éducation internationale, géopolitiques, internationalisation et relations internationales 


\section{Introduction}

This paper focuses on the media coverage of recent political spars between Canada and Saudi Arabia as well as China and their impact on Canadian universities. Two incidents initiated an avalanche of diplomatic tensions. First is a tweet from the office of Canada's Foreign Minister on August 3rd, 2018 that read: "Canada is gravely concerned about additional arrests of civil society and women's right activists in \#SaudiArabia, including Samar Badawi. We urge the Saudi authorities to immediately release them and other peaceful \#humanrights activists" (Foreign Policy Canada, 2018). Second is the arrest of Meng Wanzhou, deputy chairwoman of the board and chief financial officer of China's telecom giant Huawei, in Vancouver on December 1, 2018. Our interest in these cases stems from a curiosity to understand how an era of new geopolitics-China's rise, diminishing U.S. dominance, the possibility of a new Cold war, and economic multi-polarity-and a global political reconfiguration is impacting Canadian universities and Canada's approaches to international education (IE) (Falk, 2012; Gunn \& Mintrom, 2017; Jones, 2017).

Scholarship on higher education and media acknowledges the powerful role that media plays in framing education policy problems, setting policy agendas, and gatekeeping access (El Masri, 2020; Saraisky, 2015; Stack, 2007). Through a close study of three main media sources, and considering the ongoing tensions, we identified 74 articles and news releases between August 2018 and November 2019 in order to consider three questions: (1) What key issues did Canada's political strains with Saudi Arabia and China raise for Canadian universities' IE initiatives and what issues were absent? (2) What do these key issues suggest about Canada's approaches to IE in an era of new geopolitics? (3) What implications can be drawn from these cases about Canadian university-government relations in the context of new geopolitics? Organized in four sections, we start with our theoretical framework and research methodology followed by a report of our thematic findings. Finally, in our discussion we address our three research questions and conclude with three recommendations for Canada's engagement with IE in an era of new geopolitics.

\section{Theoretical Framework}

Soft power is attributed to a country's ability to affect an- other to obtain outcomes it wants through attraction rather than coercion or payment (Nye, 1990). It is centred on appeal and cultivation of attraction to alter behaviour of countries to influence policy and agenda setting (Nye, 2008). It was initially introduced to explain that Japan's economic strength in the 1980s did not mean the decline of U.S. hegemony (Cull, 2019); and presented an opportunity for the United States to advance its interests and garner global influence through appeal rather than hard/military power. It is rooted in the study of power in international relations, and in the importunity to advance interests and maintain hegemony; it is intrinsically linked to a country's public diplomacy strategy and its behaviour domestically and internationally. Each country's ability to define and exercise its soft power in international relations is circumscribed by several domestic, historical, and technological contexts (Hayden, 2012)-it is highly relational and contextual in nature.

As an analytical concept, soft power is state-centric and influenced by the realist school of thought in international relations, where states are primary actors, and their role is central to understanding soft power as they propagate it from their identity and values (Hayden, 2012; Nye, 2008). That said, the notion of the state is heavily contested. Stein and Andreotti (2015) contend that state interests are bounded by a "dominant global imaginary" rooted in Western supremacy, where the West is "understood to be at the top of a global hierarchy of humanity and human knowledge production (equated with economic success), with the rest of the world trailing behind" (p. 235). The voices of Indigenous peoples and racialized minorities are often missing/silenced in Canada's state interests. Canada, for instance, rarely acknowledges its colonial past or its contributions to a "racialized global capitalist system" (p. 229), yet continues to invest considerable resources to portray itself as a middle power, open, benevolent and multilateral in commitment. However, scholars argue that Canada's suite of domestic challenges-failures on Indigenous issues, building an oil pipeline, and political scandals-reduces its soft power (e.g., Amnesty International Canada, 2015; McClory, 2019).

There are two important considerations to weigh with relation to the theoretical framework and direction of this paper. First is the relational and contextual nature of soft power. It differs from one country to another and between countries because resources are finite and some relationships are more strategic and beneficial to pursue 
than others. It bears noting that Canada's foreign policy strategy is influenced by its colonial links to the U.K. and is considerably shaped by its geography and proximity to the United States-its largest trading partner. Second is the context of the era of new geopolitics. Scholars argue that there has been a shift away from the preponderance of western power in the world, with a transition of power towards the East, with emerging economies and countries in the global South gaining sufficient economic strength (Hill \& Beadle, 2014; McClory, 2019). Scholars also speak of this world of new geopolitics as a period of a "new cold war" between Russia and the West and increased bipolarity and competition between China and the United States (Jones, 2017, para. 4). While this new geopolitics has yet to fully take form, there is recognition of new realities where soft power is no longer a linear operation from the west to the rest. The global North no longer has a monopoly on cultivating appeal and generating soft power; emerging powers in the global South are actively strategizing and growing their soft power reserves.

\section{International Education as Soft Power}

Soft power offers a useful framework in understanding the role of governments in IE. Several scholars speak to how higher education has been recognized as a crucial soft power tool to heighten the attractiveness of a given country or culture in world politics (Nye, 2008; Peterson, 2014; Wojciuk, 2018). IE, particularly the education of international students, is frequently identified as a strong soft power resource to serve interests of specific nation states. This is because as an "international student returns to his or her native country and takes over vital positions in the public or private sector, the individual will eventually affect his or her country's trajectory and, in turn, [the host nation's] foreign policy" (Mai, 2015, para. 3). In an era of new geopolitics, higher education has a significant role to build and strengthen what Hayhoe (1989) refers to as international academic relations between countries/regions. The nature of international academic relations is such that foreign affairs provide the nexus between the federal government, universities, and IE.

Canada's IE approach was first initiated as an aspect of its foreign policy post-World War II. Its invest- ment in Overseas Development Assistance Program resulted in the arrival of funded international students in the 1960s on Canadian campuses and the opening up of international offices to manage development cooperation projects funded by the External Aid Office and later CIDA (Canadian International Development Agency; Shute, 1999). With shifting foreign policy priorities as "extension abroad of national policies" (Granatstein \& Bothwell, 1990, p. 13), there was an interest in facilitating "contacts...between Canadian and foreign scholars" (Graham, 1976) through programs such as Canadian Studies Abroad in order to achieve the Government's interest in the promotion of Canadian culture and diplomacy in the 1970s. This focus shifted yet again in the 1980 s and more so in the 1990s, when Canadian "foreign policy became trade policy" (Cohen, 2003, p. 109) and IE an important trade sector generating revenue for the Canadian economy through the recruitment of international students (Trilokekar, 2010). There has always been a link between Canadian foreign policy and IE; the Canadian government has had an interest in IE as a tool to cultivate its soft power, albeit its orientation has largely been in context of a western hegemonic world operating with colonialist perspectives towards the global South (McCartney, 2016; Stein \& Andreotti, 2015).

\section{Methodology}

Given the critical role the media plays in framing education policy issues (El Masri, 2019; Saraisky, 2015; Stack, 2007; Suspitsyna \& Shalka, 2019), we deliberately chose to analyze media coverage of these two cases, how it takes up the conversation of changed geopolitics, and its implications for IE at Canadian universities. This is particularly important in the absence of any official statements on these issues from the federal government and Universities Canada.

As mentioned, we focused on two incidents; the first, a tweet outlined above that was released from the office of Canada's Foreign Minister on August 3, 2018; the second the arrest of Meng Wanzhou, deputy chairwoman of the board and chief financial officer of Huawei on December 1,2018 . The resulting diplomatic tensions-the Saudi government recalled its ambassador and ejected the Canadian ambassador, and the Chinese government responded by detaining two Canadians in China and imposing some trade restrictions on Canadian products- 
had direct repercussions for Canadian universities. The Saudi government withdrew all its sponsored students by cancelling the scholarship program that funded their tuition and expenses. On the Canada-China front, while there have been no tangible reactions towards universities from the Chinese government, concerns remain about the influence these tensions might have on the single largest group of international students in Canada, in addition to Canadian universities' research ties withand funds from-Chinese partners, including Huawei.

We conducted a systematic scan of the Canadian digital and print media's coverage from August 2018 to November 2019. Data was retrieved from three main media sources: (a) media releases from Global Affairs Canada, (GAC) the Canadian Bureau for International Education (CBIE) and Universities Canada; (b) articles from the three highest circulation English mainstream print newspapers The Globe and Mail, National Post, and Toronto Star (Newspapers Canada, 2016); and (c) major relevant Canadian education magazines: Policy Options, Maclean's Magazine, and University Affairs. We also opted to include articles by other Canadian news outlets, such as the Canadian Broadcasting Corporation (CBC) and city-specific newspapers, captured by University Affairs to ensure the inclusion of a wider array of perspectives and voices. Using a list of key search words (China/Saudi Arabia; IE and universities), we have a final corpus of 74 articles and news releases as outlined in Table 1.

We acknowledge limitations in our methodology. We did not include French-language media and exclusively focused on the Canadian perspective (as opposed to that of Saudi, Chinese, or other foreign governments).
With that in mind, we conducted a thematic analysis as a qualitative research technique to identify, analyze and report patterns/themes within data (Braun \& Clarke, 2006). In particular, we identified narratives as they provide "an opportunity to map and re-map the connections between actors, ideas and institutions" (Lowndes, 2016, p. 103) and help identify issues, problems, consequences, and often solutions. Each of the three researchers analyzed and coded the data separately then met to compare and finalize data coding to come up with three dominant narratives.

\section{Media Narratives}

While there were several narratives, we limited our analysis to the three most dominant ones in the interest of scope and space. We also identified actors/voices that mobilize each of these narratives, and those that provide oppositional and/or counter narratives.

\section{Canadian Universities at Risk of Foreign Interference}

The most dominant narrative (32/74 data entries) is focused on China. Here, the media examined China's relationship with Canadian universities through research collaborations and influence of Chinese students on issues of academic freedom, free speech, and safe-student-spaces on Canadian campuses.

The media addressed two notions of Canadian universities' research collaborations with China, through individual researchers and/or research funding. The first is perceived Chinese espionage in the form of 2,500 spon-

Table 1

Media Articles by Source

\begin{tabular}{lclclc}
\hline & Media Releases & \multicolumn{2}{c}{ Newspapers } & \multicolumn{2}{c}{ Magazines } \\
\hline GAC & 0 & National Post & 10 & $\begin{array}{l}\text { University } \\
\text { Affairs }^{*}\end{array}$ & 31 \\
\hline $\begin{array}{l}\text { Universities } \\
\text { Canada }\end{array}$ & 2 & Globe and Mail & 19 & Policy Options & 4 \\
\hline CBIE & 1 & Toronto Star & 5 & Maclean's & 2 \\
\hline
\end{tabular}

* This number reflects the media entries compiled by University Affairs, excluding the ones already captured by the newspapers search. 
sored military scientists and engineers collaborating with universities around the world, including Canada, to gather data and information towards improving military technology (Leuprecht, 2018), effectively impacting Canadian national security and economic stability. The second is the perceived co-opting of the large numbers of Chinese faculty and researchers hosted on Canadian campuses to further Chinese interests (Quan, 2019a). International reports on China's political ambitions and risks to universities are also referenced. For example, a report by the Australian Strategic Policy Institute (Blackwell, 2019d) cites 687 collaborative papers between Canadian and Chinese researchers (Vanderklippe, 2018a) and lists Canada as the third-largest destination for China's People's Liberation Army-sponsored researchers (Connolly, 2019). Chinese defence scientists are reported to be working with Canadian scholars using names of non-existent civilian institutions in China rather than citing their military credentials (Vanderklippe, 2018a). Highly ranked Canadian universities are reported to be among the top 10 universities outside of China collaborating with the Chinese People's Liberation Army (Leuprecht, 2018). Collaborations with Huawei have come to be targeted given their funding of millions of dollars to 10 Canadian universities, with whom Huawei subsequently is reported to have obtained full licensure for the patents that are realized (Green, 2018). Huawei is also reported to have partnered with the province of Ontario in investing $\$ 212$ million for "the creation of 250 new research and engineering jobs" focused on 5G (Green, 2018, para. 25). These investments are perceived, according to a former Canadian intelligence chief, to facilitate China's "capacity to conduct remote spying and modify or steal information or even shut down systems" (Silcoff, 2019, para. 13) while gaining greater shares of intellectual property and ultimately global political and economic influence (Green, 2018).

The media also reported mounting suspicion of Chinese government influence on Canadian campuses through Chinese students (e.g., Blackwell, 2019a; Dobby \& Silcoff, 2019). Three incidents involving Chinese students were reported at different campuses: a petition to remove an elected student president who was also a Tibetan activist (CBC, 2018); a disruption of a presentation by an activist critical of the Chinese government's treatment of Uyghur (Blackwell, 2019a); and a culture of fear among Uyghur international students preventing them from publicly criticizing China (McCuaig-Johnston, 2019a). Some suggest that "the Chinese consulate [is] using students to infiltrate the academic field" (Xu \& Friesen, 2019, para. 9), raising threats to free speech and academic freedom on Canadian campuses. The Canadian context is compared in the media to the United States, Australia, and the U.K. (Connolly, 2019). Articles refer to the closure of the Confucius Institutions in the United States and Australia and the cancellation of research funds and collaborations with Huawei in prominent American and British institutions (Bothwell, 2019; Hager, 2019; McCuaig-Johnston, 2019b). Media sources reference Australian universities' commitment to a new code that requires them to share cyber intelligence with national security agencies, name overseas research partners, and list financial dealings with other countries. Effectively, reports allude to universities becoming subject to tougher requirements when collaborating with foreign countries on research (VTN News Network, 2019). In contrast, the media reports that Canadian universities continued to maintain their relationships with Huawei (Silcoff, 2019), which is perceived as "naivete on the part of the academic sector" (Blackwell, 2019b, para. 5). However, university administrators are quoted arguing that national security issues are the responsibility of the government, as universities cannot "make assessments on issues of national security" (Vanderklippe, 2018b, para. 10). Universities also highlighted that their commitment to academic freedom precludes their regulating areas of research pursued by faculty or graduate students (Vanderklippe, 2018b). After all, international scientific collaboration "is an essential part of being a research-intensive global university" (Vanderklippe, 2018a, para. 35) and that "politicizing science, because of tensions between two countries" is unacceptable (Blackwell, 2019c, para. 6).

Central to this narrative is the voice of the Canadian Security Intelligence Service (CSIS) that brings to the forefront the security risks for Canada when it engages in research collaborations and hosting Chinese students and scholars on Canadian campuses. Media narratives reference a secret CSIS report that was said to have been shared with Ministers of the Federal Government, key Canadian research universities, and associations like Universities Canada, but not available to the public at large (see Berthiaume, 2019; Blackwell 2019c; Vanderklippe, 2018a; Quan, 2019a). Supporting 
the CSIS warnings are quotes in the media by faculty and subject experts in international/global affairs, public policy, and cyber security as well as select former diplomats. Several research universities and some K-12 public school boards are listed amongst these media narratives. Individual students implicated in this controversy, such as the University of Toronto Scarborough elected student president and the Uyghur international students, are also heard as voices supporting this narrative. In mobilizing this narrative, reference is made to how prominent universities in Australia, the U.K., and the United States (examples given of Oxford, Stanford, and MIT) are aligning their policies with national security agendas. The media also reported that the Chinese Embassy and Consulates reject the view of national security threats for Canada. Additionally, Universities Canada and individual Canadian universities speak to the importance of continued IE activity and collaborations between Canada and China.

\section{Canadian Universities' Financial Sustainability at Risk}

This second narrative (28/74 data entries) focused on highlighting how the lucrative IE business can face tremendous economic consequences as a result of diplomatic rifts. It reported concern with the increased dependence of Canadian universities on international student revenue. It promoted better risk management strategies on the part of both Canadian institutions and the governments in light of this dependence.

The media raised concerns that the new political climate would harm student recruitment. The articles reported how the outcome of the fall-out with Saudi Arabia affected nearly 6,000 Saudi students and how "Canadian universities and colleges...lost $\$ 140$ million in revenues as a result of the sudden disappearance of all these students" (Usher, 2018, para. 1). The Council of Ontario Universities is reported as warning the public that "Ontario institutions alone stand to lose tens of millions of dollars, not including the overall economic impact from housing and living costs" (University Affairs, 2019, para. 8). Several articles speak of how this impact is felt in both small and large provinces/universities, given that this revenue represents "more than the auto parts and lumber industries in Canada" (Arabian Business, 2018, para. 14). Ultimately, reports stated a softened Saudi position "mitigated some of the anticipated cost to Canadian universities"
(Friesen, 2019b, para. 7). However, media highlights that the Saudi experience exposed universities as "financially vulnerable to the vagaries of international politics and economics"(Usher, 2018, para. 7); notwithstanding, "the impact on revenue was relatively contained given that Saudi students comprised only a small component of international students" (University Affairs, 2019, para. 12). The media reported how the Saudi incident has made many wonder: What might happen if China put a "halt to the exodus of hundreds of thousands of Chinese students abroad every year?" (Usher, 2018, para. 8).

In the days following the arrest of the Huawei executive, reports spoke to how universities scrambled to assess the impact that rising Canada-China tensions could have on student enrolment, fundraising, and research. Internal records show concerns of potential "credit risks for Canadian universities" (University Affairs, 2019, para. 7). As the largest source of international students in Canada, the media further expressed concern that "some Chinese students may be deterred by the current crisis" since "Canada is...receiving bad publicity in the Chinese state media" (Bothwell, 2019, para. 13). Chinese study abroad agencies are reported to be taking defensive measures in less enthusiastically promoting Canada (Yi, 2018). Since a relationship with China is crucial to the billion-dollar IE industry, university presidents were reported as having discussed the issue privately (Friesen, 2019c). There is clear recognition that "China remains important for Canada's universities," hence, "we've [Universities Canada] been in touch with Global Affairs just so they're aware how important the relationship is to us and to Canada's economy" (as quoted in Friesen, 2019c, para. 7). Several Canadian universities with significant foreign student populations said they have yet to see evidence of a decline in Chinese enrolments (Du, 2019). However, others reported that certain specialized programs have been impacted (Vanderklippe, 2019; Quan, 2019b).

The media spoke to how concerns over possible interruptions of international student flows prompted both the federal government and universities to take measures. Federally, "the Saudi experience galvanized [federal] government attention" (Lewington, 2019, para. 19). Concerned that more than half of the international students in Canada come from just two countries, China and India, the federal government has pledged nearly $\$ 30$ million over the next five years to diversify the source countries for recruitment. The articles reported 
how the government targets countries with a large and growing middle class that may not yet have the higher education capacity to educate all their students (Friesen, 2019a). Institutionally, Canadian universities are "adding scholarships, hiring education agents, opening overseas offices, establishing overseas partnerships and recruiting alumni as word-of-mouth ambassadors" (Lewington, 2019, para. 4) to counter stiff competition for international students, and to be agile in the current era of new geopolitics. They report that university administrators learned that "unpredictable events beyond a university's control require officials to learn to be nimble... [and] never sit comfortably with the [student] population" (Lewington, 2019, paras. 39-41).

At the forefront of mobilizing this narrative are organizations representing Canadian university interests, most notably Universities Canada, but also the Canadian Bureau of International Education, the Conference Board of Canada, and the Council of Ontario Universities. In addition are a list of individual universities-research-intensive such as Toronto, McGill, British Columbia, and Waterloo, who speak to the importance of Huawei research funding, and York, Lakehead, New Brunswick, and PEI, among others-who either enrolled students from Saudi Arabia or have large numbers of Chinese international students. Few colleges are represented-Mohawk and Niagara are examples of those who lost a number of Saudi students. Among the voices heard are those of China-specific programs, such as York's Schulich School of Business Asia Management Program, the University of British Columbia's China Council, and other China and Asia specialists who run IE programs in China. Adding to these institutional voices are those of the Teaching Hospitals and the Royal College of Physicians and Surgeons as actors that faced the negative repercussions of the Saudi Arabian government's decision to withdraw its scholarship students. This narrative is given further credence through the mention of impact studies on financial risks and associated losses produced by Moody Investor Services (Wong, 2019). The Government of Canada's voice is represented through Statistics Canada and Global Affairs Canada's policy imperative to diversify Canada's international student body. The student voice heard is that of Saudi students who speak to the disruption of their otherwise enjoyable and rich experience at Canadian higher educational institutions. There were no voices reported countering this narrative.

\section{Universities Critical to Meeting Canada's Future Global Success}

The third narrative (12/74 data entries) recognized that Canada cannot afford to ignore emerging global powers. As Vice-Chancellor of the University of Waterloo, Feridun Hamdullahpur suggested, "Now it's time to move past the 'China-is-rising' narrative" and "recognize that economic winds blow to the East" (Hamdullahpur, 2019, para. 1). As China and India are predicted to overtake the United States as the world's top economies by 2030 , Canadian business and civil society leaders should invest in building "Asia competencies" in language, culture, and business "so that this generation is ready to engage effectively with one of the largest economies in the world" (Davidson, 2018, para. 8). Articles suggested that "more needs to be done to ensure that the next generation of Canadians are confident, skilled and culturally prepared to engage with China in diplomacy, trade, science, education, tech and beyond" (Kim \& Touch, 2019, para. 7). They stated an urgent need for Canadians to invest in

"China competencies" today, regardless of whether we consider China a friend or a foe. Now is not the time to scale back on our engagement with China. On the contrary, if we want to win our 'hundred battles,' we ought to be scaling it up. (Kim \& Touch, 2019, para. 13)

Therefore, Canada should invest in educational exchanges with China (and other emerging powers) to meet its future diplomatic, trade, economic, and technological needs.

Whereas Chinese research collaborations and large student presence at Canadian universities were a source of scepticism in the first narrative, they were perceived to present opportunities for Canada here. The media reported that the value of the Chinese "alumni network to building lasting relations in China cannot be overestimated" (Davidson, 2018, para. 10). Additionally, "China's vast and growing middle class represents more than simply consumers; this is a generation of people who want to be global citizens, and they want that for their children, too" (Beck, 2018, para. 2). Therefore, Canada's educational and research connections with China "have enormous value and represent significant opportunities for our country" (Beck, 2018, para. 2). The focus, 
the articles suggest, should be on "getting the relationship right with China as this will have both immediate and long-term consequences for Canadians" (Davidson, 2018, para. 13). The post-secondary education sector is identified as best poised to play a leadership role in fostering such partnerships and preparing the next-generation workforce to do business globally, particularly in Asia, and specifically in China. Investing in more international research and development collaborations and study abroad for Canadian students is considered crucial. Articles critique the "one-way street" in our partnership, because "Chinese students who come to Canada develop a high 'Canadian competence,' and those who return home take it with them. It's a loss for Canada and a gain for China" (Beck, 2018, para. 8). Articles urge that "universities should be at the forefront of bridging the gap [because]....if...[they] don't, our countries in the West are sure to fall behind one business venture, one research discovery and one person at a time" (Hamdullahpur, 2019, para. 17).

Supported by fewer articles, this narrative is supported by organizations invested in Canada's trade relations with Asia, mainly China. Examples include the Asia Pacific Foundation of Canada, Global Affairs Canada, Minister for Trade Diversification, and select Trade Commissioners and Canadian Ambassadors to China. Universities Canada remains an active supporter, including individual universities with collaborative programs and ventures with China. Examples include the Ottawa-Tsinghua partnership and the University of Western Ontario's research partnerships with China supported by the London mayor, London's economic development corporation, and Western's President and individual faculty members. Ironically, this narrative uses the U.K. and the United States as examples of countries that invest much more than Canada when it comes to IE relations with China. There are no student voices reported speaking to this third narrative. David Mulroney, former Canadian diplomat to China, and a few members of the Conservative party are voices mentioned as opposing this narrative.

\section{Discussion}

In response to our first research question (what key issues or concerns did Canada's political strains with Saudi Arabia and China raise for Canadian universities' IE initiatives), the three media narratives illustrate the impact of (shifting) geopolitics on Canadian IE initiatives. The first narrative speaks to China's rising global power as cause for national security concerns and violation of freedom of speech and academic freedom on Canadian campuses. The national security agenda raised in this narrative is a relatively new conversation-the only other reference in the media made post-9/11, when CSIS interviewed Muslim international students indiscriminately. This is likely a reaction to how China has globally positioned itself and has consistently and concertedly invested in expanding its reach and influence. China is perceived as an indispensable and growing power with a robust soft power strategy because of how it developed its outreach (Seib, 2016). It cultivated its cultural and soft power assets-starting with sending a few pandas to zoos abroad in 1990s, to developing a sophisticated operation that ranged from hosting the Olympics in 2008 and World Expo in 2010-to build relationships and establish trade and security networks (Seib, 2016). Canada is likely influenced by the strong national security narrative in IE discourses in the United States (Campbell, 2005; Trilokekar, 2015). It is worth stressing that issues of national security, freedom of speech, and academic freedom only arise in reference to China as Saudi Arabia is not perceived to pose a (security) threat. Giving voice to CSIS, cyber security experts, and international affairs experts, the media managed to create a sense of crisis in context of this narrative, hence representing IE as a national security threat.

While the first narrative spoke to the politics of IE, the second and third narratives focused on the economic impact for Canada and its universities. Supported by (representatives of) Canadian universities, the second narrative speaks to the tremendous economic impact international students have on universities and communities, given the withdrawal of Saudi students from Canadian universities and an impending crisis if Chinese students stop enrolling in Canadian universities. It is clear that interests lie in protecting IE as a business strategy. The third narrative, while largely focused on economic benefits for Canada as a nation, is globalist in nature. It recognizes a new geopolitical order and the growing importance of Asian countries like China and argues for Canada's engagement in more active two-way educational exchanges with partner countries (unlike the one-way, inward-looking focus of the second narrative). 
It speaks to more investment in IE versus the second narrative that speaks to IE solely as income. To conclude, all three narratives address the impact of the political fall-outs with China and Saudi Arabia on Canadian universities. The focus is on distinctly different impacts: political exposure and vulnerability of Canadian universities to foreign governments; economic dependence of Canadian universities on revenue from foreign students; and the need for IE to enable Canada to remain competitive in a fast changing world of new and rising powerful economies. Media articles largely mobilize the first narrative, framing IE as a vehicle for foreign governments to infiltrate Canadian universities and society, and thus construct IE as problematic and risky.

Our second research question was: What concerns do these cases raise about Canadian approaches to IE in an era of new geopolitics? Interestingly, before the fall-out with Saudi Arabia and China, Canada's success in recruiting international students who chose Canada because of its reputation was lauded, as Canada was "especially appealing at present given current geopolitical realities [emphasis added]" (Hoult, 2019, para. 2). Canadian universities were perceived to be winners in comparison to competitor countries that significantly restricted immigration regulations for international students; a manifestation of counter-globalisation, anti-liberalisation and anti-immigration sentiment-results of developments like Brexit, and the election of Donald Trump as President of the United States. The so-called "Trump bump" was celebrated as "international students and faculty who might once have considered America the best place to get an education are fleeing our southern neighbour" (Paikin, 2019, para. 3). Canada capitalised on its image as "a beacon of stability, openness, tolerance and inclusion," and is "seen as an increasingly rare bright light on the world stage" (Gertler, 2016, para. 6). In a strategic soft power move, the Government of Canada's updated IE strategy was labelled: Building on Success: International Education Strategy (2019-2024).

The media articles, however, suggest a more cautious and critical perspective on Canada's IE approaches. This is particularly evident in the second and third narratives. The second narrative forewarns the economic vulnerability of Canadian universities as they become increasingly dependent on single markets like China or Saudi Arabia, and recommends securing this income stream by diversifying Canada's trade portfolio in educa- tion by entering new markets and diversifying its source countries of international students (GOC, 2019, p. 4). It maintains the status quo of IE as trade or business for the central purpose of protecting Canada's economic benefits. While IE may be impacted by political tensions, it is not considered an inherently political activity, nor one that is dramatically shifting in its very nature under new and emerging geopolitical contexts. The third narrative critiques Canada's short-sighted approach to IE and advocates for investment in more IE initiatives keeping borders and investments in two-way relationships yet it is motivated by securing Canadian economic interests.

While the first narrative is not directly critical of IE, it speaks to its role in raising issues of national security and academic freedom. This construction of IE could instigate a backlash against Canada's engagement in IE, as it mobilizes colonial and discriminatory narratives. Scholars warn that the construction of Chinese students as activists and China as a threat to "corrupting the core value of the Western world that lie at the heart of our universities' freedom" (Suspitsyna, 2015, p. 31) reproduce persistent colonial imaginaries of the Orient or the "post-colonial other" (Suspitsyna \& Shalka, 2019, p. 287). Lee and Rice (2007) speak of these imageries in the media as reproducing neo-colonial and neo-racist discourses on campuses based on an individual's country of origin. Positioning China on the one hand as risky for contaminating the culture, value, and traditions of Canadian universities, and on the other hand as a threat to West's economic, academic, and political superiority epitomize the (white) fear of being engulfed by difference that upsets the assumed hierarchies of cultures, races, and ethnicities (Suspitsyna, 2015; Suspitsyna \& Shalka, 2019).

There is an absence of discussion in the media that recognizes the limitations of Canada's IE approach in context of new developments. Scholars allude to how, in this new world of geopolitics, many countries have witnessed a steady-if not sharp-increase in investment in soft power resources and cultivation (McClory, 2019). The Soft Power 30 (McClory, 2019) identifies six categories to measure and rank soft power in thirty countries, with education being a key category. Since the 1990s, international branch campuses have sprouted across Asia and the Middle East, with these regions developing as educational hubs attracting international students from within the region and offering expanded 
opportunities for their own citizens. Asia is at the helm in engaging with the world, investing heavily in education and infrastructure, creating targeted public and cultural diplomacy programmes and initiatives, and challenging the decades old privilege of Western organizations like the Organisation for Economic Co-operation and Development (OECD) and Group of Seven (G7) and their interests (Mok, 2012; Sinclair, 2017). Sinclair (2017) proclaims that the most radical change that Canada's worldview needs to take into account is the emergence of the global South as a major driver. Palamar and Jardine (2012) and Gurry (2012) speak of India and China as the future giants of world higher education in what is spoken of as the Asian century (Morgan, 2016). China has two centrepieces to its foreign policy agenda: an ever-expanding network of Confucius Institutes and The Belt and Road Initiative allowing it to engage with 138 countries (Belt \& Road Portal, 2019). It has moved away from a solely inward orientation in internationalization (importing higher education models from abroad) to a distinct outward engagement (positioning itself as emerging global models of higher education). China's rising power as a major player claiming regional and global leadership is associated with its investments in IE as soft power in its own image (Li, 2018), resulting in its attractiveness as an IE destination. This is a different world from the post-World War II world when Canada was largely advantaged in IE. Today, new mobility patterns include South-South models of collaboration, breaking the traditional South-North pattern.

In the media, there are no questions asked or challenges put forth for Canada's approaches to IE given these shifting geopolitical contexts. The university community in particular is silent, suggesting that these concerns are arguably far from the minds of most of our policy makers. How should global South initiatives and IE initiatives in Asia influence our approach to IE? How can domestic priorities of decolonization, indigenization, and equity, diversity, and inclusion within Canadian higher education redefine our approaches to IE within this new geopolitical context? What can Canadian soft power enable with regards to our engagement with IE as a political versus a purely economic enterprise? These important questions remain unaddressed. It is within this context that we recommend taking action in the form of developing a comprehensive foreign policy and IE strategy that is grounded in what we label as engaged soft power. Engaged soft power is a reorientation of focus that acknowledges the projection and the reception of the manifestations of soft power, as a two-way street. It is based on a fundamental premise that the West no longer dominates the projection of soft power, but is also a recipient, and thus challenges earlier notions of power and hegemony. Sinclair (2017) encourages Canada to adopt "inclusive approaches, not hold on to shaky privilege," "favour multilateral approaches," and "create new partnerships of our own with key nations of the global South," urging Canada to realize that "today's uncertainty should make it clearer than ever why we need to move beyond a global perspective largely shaped by relations with the U.S. and EU" (para. 16). Canadian foreign policy has been economically focused for nearly three decades, but the current geopolitical landscape suggests the need for more informed and engaged strategy that can weather diplomatic storms and not run the risk of significant economic or political repercussions.

Our third and final question was: What implications can be drawn from these cases about Canadian university-government relations in the context of geopolitics? Media articles described university-government relations in three distinct ways. The first narrative reinforced a view that universities are direct arms of the government. In this case, media articles reference how Australian universities were asked to report collaborations with any foreign entities and how international agreements signed by universities need to come under government regulations, implying they should be in sync with the government's foreign policy priorities. Canadian universities were also portrayed as naive in operating independently of the government (Blackwell, 2019a). Media articles that spoke to the vulnerability of Canadian universities to foreign interference further stoked these sentiments by comparing governmental or organisational policies in the United States, U.K., and Australia that have "made clear that internationalisation as a goal in itself is to be secondary to the country's global advancement and security interests" (Lee, 2019, para. 1). As Marginson (2019) states, "we have been brutally reminded that politics is primary, and when government sneezes then universities catch cold. When government is threatened, or its fundamental interests are at stake, then universities will be expected to conform" (para. 1). The media alluded to secret meetings between CSIS and select Canadian universities and Universities Canada, 
however, the details about these meetings is not known. It can, however, be assumed that universities are recognizing government concerns regarding possible foreign interference. The second and third narratives reinforce the role of universities as serving broader governmental economic and trade agendas and thus, as working in cooperation with the government to secure these goals. IE is viewed here as essentially a non-political venture, pursued by both governments and universities to serve Canada's national economic interests. In this sense Canadian universities are perceived as national institutions fulfilling the broader goals of the Canadian government's interests in maintaining Canada's economic advantages, nationally and internationally.

Running through the first narrative is an implicit but oppositional perspective that universities are distinct actors from governments, whose purpose is to pursue "Science vs. Security" (Lee, 2019, para. 21), i.e., a view that sees "universities, as global knowledge producers and disseminators [that should] not [be] bordered in the changing political climate by a perceived [national] threat" (Lee, 2019, para. 16) precisely because the role of the university is distinct from that of the government. University researchers and faculty members who are invested in maintaining institutional autonomy, academic freedom, and international scientific collaboration mostly voice this view and speak of the dangers of politicizing science (see for example, Blackwell, 2019b; Vanderklippe, 2018a). This is a notion referenced as scientific globalism, which views science as universal and not bound by any political borders. Science is guided by norms established by the scientific community, and therefore the knowledge derived through scientific enquiry is accessible to all (Sá \& Sabzalieva, 2018). It supports the view that "limiting international ties and curbing knowledge production within a bordered bubble will not benefit any nation-state or global society" (Lee, 2019, para. 50). While this perspective is not explicit and not one that is elaborated within the media articles, it is a view that is central to our concept of engaged soft power. Universities are the most ideal vessels for the development of an IE strategy precisely because their commitment to collaboration is boundless. As receptors of soft power projections, they engage with a multitude of perspectives, values, and ideologies-inspiring and advocating for an engaged soft power strategy. However, what is paramount is that in this endeavour universities carve their own unique niche and role. Universities have a role to play in reminding governments that they need to engage in a foreign policy that is both outward looking and globally engaged, keep their borders open to allow mobility both in and out of their academic institutions, but perhaps most importantly, respect and allow for university autonomy and academic freedom with minimum government oversight and control of IE programs. This will allow universities to contribute to what they do best: promote free flow of ideas, collaboration, and partnership within and across people and borders.

\section{Conclusion}

Canadian media coverage of educational matters tends to be strongly linked to global, national, and provincial geopolitical and socio-economic events, particularly those that are "new, controversial, and [have] an immediate impact on the public's lives and interests" (El Masri, 2020, p. 377). Our research revealed that the media actively discussed the impact of Canada's fall-out with Saudi Arabia and China on Canadian Universities. It also raised concerns about Canada's approaches to IE in two ways; first, as a risk to national security and maintaining Canada's power and hegemony as part of the western world. Second, it illustrated IE as the vehicle for Canada's economic prosperity and in turn its global economic power and hegemony. However, what the media has not achieved is a broader discussion on how Canada needs to revisit its IE objectives and approaches in light of broader geopolitical shifts. The two cases we examined serve to vividly illustrate the close tie between global politics, government foreign policy, and IE within Canadian Universities. Moving forward, Canada's approach to IE has to be visioned and imagined in the context of new and shifting geo-politics and its commitments to decolonization and the rights of Indigenous and racialized minorities. This is what we label as an engaged soft power approach, a reorientation of focus that acknowledges the projection and the reception of the manifestations of soft power, including IE, as a two-way street.

We outline three recommendations moving forward. First, Canada's approach to IE as business as usual has to change. The current context of the COVID-19 pandemic reveals gaps in Canada's IE approaches. The primary concern across governments and universities is reduced to international enrolment and subsequent 
loss in revenue (Usher, 2020). This sentiment speaks to a stubborn prevalence in perceiving IE as revenue generating, and assuming Canada's global attractiveness. Marginson (2019) speaks about changing global mobility trends during and post COVID-19 suggesting that part of the East-to-West student traffic will shift into East Asian mobility traffic permanently. He argues that East Asia will now rise further in IE "because of strong health and governance regimes and the bounce back factor" (para. 18). Second, in engaging IE as soft power, Canada has to challenge its basic assumptions of Western supremacy and make genuine efforts towards more collaborative, mutually beneficial partnerships. During the COVID-19 period, there have been signs of Sinophobia where Chinese students (and Canadian Chinese nationals) reported racism and anti-Asian sentiments in Canadian universities and in broader society (Moir, 2020; Leach, 2020). These sentiments speak to the limiting impact IE has had in understanding the other and our vulnerability in falling back on superior colonial Western imageries. Third, Ang et al. (2015) suggest:

...cultural diplomacy can move beyond the national interest [and towards greater mutuality] only if this move itself can be understood as being in the national interest. Further research, including in other countries and regions, is required to finesse the implications of this understanding. (p. 379)

Conversations about the need for a new IE approach in the context of geopolitics needs to be picked up by the media. This is where the role of the universities, scholars, academics, and students is paramount.

It is important to consider whose voice is present and absent in supporting media narratives. Based on the tally of media articles reviewed (see Table 1) most are from specialized newsletters that circulate among specific professionals versus that reach the general public. Also, whereas Global Affairs Canada, Universities Canada and the Canadian Bureau of Education-all organizations with vested interests in IE-respond to newspaper queries, they do not proactively put forth position statements on this subject. The actors whose voices support each of three narratives reveal their inherent investment in perpetuating them. The first narrative represents the voice of national security experts, with CSIS most prominently represented; the second, university representatives that enjoy the most direct economic gains from IE; and the third, professionals invested in Canada-China trade relations. In examining the IE higher education policy context in Canada, El Masri (2020) observes that, while the media offered a platform for very diverse players to express opinions, access to this platform was not even. Whereas politicians, civil servants, and economic, foreign affairs, business and trade experts and professionals' voices were strongly present in the media's coverage of educational matters, the presence of faculty members, particularly post-secondary education and IE scholars, was very limited (EI Masri, 2019). Similar to El Masri's $(2019 ; 2020)$ findings, the voices heard in the media are mainly university upper administrators. If individual faculty researchers are quoted, they are faculty in economics, business and international affairs, while voices of faculty and scholars of post-secondary education and IE are missing. In this mediatized age, El Masri (2020) argues that the media has created new political stages and provided access to (new) actors. We concur with El Masri's (2019) call for IE scholars and faculty members to serve as public intellectuals in the media in an effort to reshape IE discourses in Canada; building awareness among the general public about IE-its value and benefits as well as the intrinsic tie between national and broader global benefits.

\section{References}

Amnesty International Canada. (2015). UN human rights report shows that Canada is failing Indigenous

peoples. https://www.amnesty.ca/news/public-statements/joint-press-release/un-human-rights-reportshows-that-canada-is-failing

Ang, I., Isar, Y. R., \& Mar, P. (2015). Cultural diplomacy: Beyond the national interest? International Journal of Cultural Policy, 21(4), 365-381. https://doi.org/10. 1080/10286632.2015.1042474

Arabian Business. (2018, August 9). How Saudi-Canada spat could end the dreams of many students. Arabian Business. https://www.arabianbusiness.com/ education/402574-how-saudi-canada-spat-couldend-the-dreams-of-students

Beck, S. (2018, April 17). Canadian students researchers key to ties with China. Policy Options. https:// policyoptions.irpp. org/magazines/april-2018/canadian-students-researchers-key-ties-chinal 
Belt and Road Portal. (2019, April 12). List of projects of the Belt and Road Initiative. Belt and Road Initiative Official Website (Chinese). https://www.yidaiyilu. gov.cn/info/iList.jsp?tm id=126\&cat id=10122\&info id=77298

Berthiaume, L. (2019, July 12). Chinese-Indian communities in Canada can be used for hostile-state activity: officials. University affairs- Global News. https://globalnews.ca/news/5490095/canada-china-india-communities-hostile/

Blackwell, T. (2019a, February 21). Student groups call for probe of China envoys; 'Interference'; Accuse embassy on Uyghur, Tibet incidents . National Post. https://nationalpost.com/news/ student-groups-call-for-ottawa-to-investigate-alleged-interference-by-chinese-officials-on-canadian-campuses

Blackwell, T. (2019b, July 12). Indicted McGill professor was caught in broad, controversial U.S. dragnet of Chinese-background scientists. National Post. https://nationalpost.com/news/indicted-mcgill-professor-was-caught-in-broad-controversial-u-s-dragnet-of-chinese-background-scientists

Blackwell, T. (2019c, July 18). 'It's kind of politicizing science'; expert's lab removal analyzed. National Post. http://ezproxy.library.yorku.ca/login?url=https:// www-proquest-com.ezproxy.library.yorku.cal docview/2259742662?

Blackwell, T. (2019d, July 31). Beware of rummaging colleagues, spies and foreign visitors: Unique FBI document warns academia about China threat. National Post. https://nationalpost.com/news/ beware-of-rummaging-colleagues-spies-and-foreign-visitors-unique-fbi-document-warns-academiaabout-china-threat

Bond, S., \& Lemasson, J. P. (1999). A new world of knowledge. Canadian universities and globalization. International Development Research Centre.

Bothwell, E. (2019, January 24). Canada fears China crisis will curtail student recruitment boom. University Affairs. https://www.timeshighereducation. com/news/canada-fears-china-crisis-will-curtail-student-recruitment-boom
Braun, V., \& Clarke, V. (2006). Using thematic analysis in psychology. Qualitative Research in Psychology, 3(2), 77-101. https://doi. org/10.1191/1478088706qp0630a

Campbell, D. (2005). International education and the impact of the 'war on terrorism.' Irish Studies in International Affairs, 16, 127-154. https://www.jstor. org/stable/30001939

Canadian Broadcasting Corporation. (2018, August 17). China denies role in backlash against Tibetan students' election at $U$ of T. CBC News. https://www. cbc.ca/news/canada/toronto/china-denies-role-inbacklash-against-tibetan-student-s-election-at-uof-t-1.5021226

Cohen, A. (2003). While Canada slept: How we lost our place in the world. McClelland \& Stewart.

Connolly, A. (2019, August 25). Chinese influence in Canada 'alive and well' says student leader threatened by trolls. Global News. https://globalnews.cal news/5804742/chinese-influence-canada/

Cull, N. J. (2019). Public diplomacy: Foundations for global engagement in the digital age. Polity Press.

Davidson, P. (2018, October 12). Opinion: Engaging with China for the long haul. Universities Canada. https://www.univcan.ca/media-room/media-releases/engaging-with-china-for-the-long-haul/

Dobby, C., \& Silcoff, S. (2019, February 22). Huawei vows to keep intellectual property in Canada. The Globe and Mail. https://www.theglobeandmail.com/ business/article-huawei-promises-to-keep-intellectual-property-in-canada-as-it-makes-prl

Du, X. (2019, Mar 1). China spat concerns UPEI students. The Journal Pioneer. https://www.journalpioneer.com/news/local/china-spat-concerns-upei-students-288548/

El Masri, A. (2019). International education as policy: A discourse coalition framework Analysis of the construction, context, and empowerment of Ontario's international education storylines [Unpublished doctoral dissertation]. York University.

El Masri, A. (2020). Who speaks for international education? An Ontario case study. In R. Trilokekar, M. 
Tamtik, \& G. Jones (Eds.), International education as public policy in Canada (pp. 358-383). McGill-Queen's University Press.

Falk, R. (2012). Is there a new geopolitics? A new form of geopolitics is threatening to dethrone the old paradigm of a hard power, West-centric world. AlJazeera. https://www.aljazeera.com/opinions/2012/8/13/is-there-a-new-geopolitics/

Foreign Policy Canada [@CanadaFP]. (2018, August 3). Canada is gravely concerned about additional arrests of civil society and women's rights activists in \#SaudiArabia, including Samar Badawi. We urge the Saudi authorities to immediately release them and all other peaceful \#humanrights activists [Tweet]. Twitter. https://twitter.com/CanadaFP/status/1025383326960549889

Friesen, J. (2019a, August 26). Ottawa unveils plan to attract students from broader array of countries. The Globe and Mail. https://www-proquest-com.ezproxy. library.yorku.ca/docview/2279626889

Friesen, J. (2019b, February 4). After diplomatic spat, fewer Saudi students left Canada than initially feared. The Globe and Mail. https://www.theglobeandmail. com/canada/article-after-diplomatic-stand-off-fewer-saudi-arabian-students-left-canada/

Friesen, J. (2019c, January 7). Universities maintain relations with China to protect international-student enrolment. The Globe and Mail. https:/l www-proquest-com.ezproxy.library.yorku.cal docview/2164069592

Gertler, M. (2016, July 21). A strategic moment for Canada. The Globe and Mail. https://www.theglobeandmail.com/opinion/a-strategic-moment-for-canadal article31019860/

Government of Canada. Global Affairs Canada (2019). Building on Success: International Education Strategy 2019-2024. Ottawa: Global Affairs Canada. https://www.international.gc.ca/education/assets/ pdfs/ies-sei/Building-on-Success-International-Education-Strategy-2019-2024.pdf

Graham, J. (1976). Recent growth of interest in Canadian studies abroad. International Perspectives: Journal of Foreign Policy, 38-42.
Granatstein, J. L., \& Bothwell, R. (1990). Pirouette: Pierre Trudeau and Canadian foreign policy. University of Toronto Press.

Green, M. (2018, December 12). Huawei well-positioned in $5 \mathrm{G}$ race to the future. Toronto Star. https:II www-proquest-com.ezproxy.library.yorku.cal docview/2157923486?

Gunn, A., \& Mintrom, M. (2017). The changing shape of global higher education geopolitics. University World News. https://www.universityworldnews.com/ post.php?story=20170529151430202

Gurry, M. (2012). India, the new centre of gravity: Australia-India relations under the Howard government. South Asia: Journal of South Asian Studies, 35(2), 282-305. https://doi.org/10.1080/00856401.2011.6 33299

Hager, M. (2019, January 28). Huawei CFO defends partnerships between company, universities. The Globe and Mail. https://www.theglobeandmail. com/canada/article-meng-defends-university-huawei-partnerships/

Hamdullahpur, F. (2019, January 25). How universities can lead our country into a new economic world. The Globe and Mail. https://www.theglobeandmail. com/business/commentary/article-how-universitiescan-lead-our-country-into-a-new-economic-world/

Hayden, C. (2012) The rhetoric of soft power: Public diplomacy in global contexts. Lexington Books.

Hayhoe, R. (1989). China's universities and the open door. OISE Press.

Hill, C., \& Beadle, S. (2014). The art of attraction: Soft power and the UK's role in the world. The British Academy.

Hoult, J. (2019, February 15). Another record year for Canadian international education [Press release]. Canadian Bureau for International Education. https://cbie.ca/another-record-year-for-canadian-international-education/

Jones, B. (2017, November 28). Order from chaos: The new geopolitics. Brookings Institution. https://www. brookings.edu/blog/order-from-chaos/2017/11/28/ the-new-geopolitics/ 
Kim, D., \& Touch, D. (2019, August 23). Having young Canadians in China is valuable as tensions rise. Policy Options. https://policyoptions.irpp. org/magazines/august-2019/having-young-canadians-in-china-is-valuable-as-tensions-rise/

Leach, J. (2020, 14 May). From SARS to COVID-19: Putting the spotlight on anti-Asian racism. Ryerson Today. https://www.ryerson.ca/news-events/ news/2020/05/from-sars-to-covid-19-putting-thespotlight-on-anti-asian-racism/

Lee, J. (2019, November 9). Universities, neo-nationalism and the 'China threat'. University World News. https://www.universityworldnews.com/post.php?story $=20191105074754722$

Lee, J. L., \& Rice, C. (2007). Welcome to America? International student perceptions of discrimination. Higher Education, 53, 381-409. https://doi. org/10.1007/s10734-005-4508-3

Leuprecht, C. (2018, November 12). China's silent invasion of western universities. Toronto Star. https:/l www.thestar.com/opinion/contributors/2018/11/12/ chinas-silent-invasion-of-western-universities.html

Lewington, J. (2019, November 4). Why universities are trying to recruit overseas students from as many places as possible. Maclean's. https://www.macleans.ca/education/why-universities-are-trying-todiversify-where-overseas-students-come-from/

Li, E. (2018, August 20). The rise and fall of soft power. Foreign Policy. https://foreignpolicy.com/2018/08/20/ the-rise-and-fall-of-soft-power/

Lowndes, V. (2016). Storytelling and narrative in policymaking. In G. Stoker \& M. Evans (Eds.), Evidence based policymaking in the social sciences: Methods that matter (pp. 103-122). Policy Press.

Marginson, S. (2019, November 16). How should universities respond to the new Cold War? University World News. https://www.universityworldnews.com/ post.php?story=20191112103413758

Mai, D. (2015, April 2). Education drives America's strongest soft power resource. The HOYA. https:ll www.thehoya.com/education-drives-americas-strongest-soft-power-resourcel
McCartney, D. (2016). Inventing international students: Exploring discourses in international student policy talk, 1945-75. Historical Studies in Education, 28(2), 1-27. https://doi.org/10.32316/hse/rhe. v28i2.4457

McClory, J. (2019). The soft power 30: A global ranking of soft power. USC Center for Public Diplomacy. https://softpower30.com/wp-content/uploads/2019/10/The-Soft-Power-30-Report-2019-1. pdf

McCuaig-Johnston, M. (2019a). Canada's universities and colleges are navigating challenges created by China. Hill Times Opinion. https://www.hilltimes. com/2019/09/09/canadas-universities-and-colleges-are-navigating-challenges-created-by-china/213593

McCuaig-Johnston, M. (2019b). Now is not the time to expand research partnerships with Huawei. The Globe and Mail. https://www.theglobeandmail.com/ opinion/article-now-is-not-the-time-to-be-expandingresearch-partnerships-with-huaweil

Moir, M (2020, 27 May). Despite hesitations, these Chinese students say they still plan to study in Canada. University Affairs. https://www.universityaffairs.cal news/news-article/despite-hesitations-these-chinese-students-say-they-still-plan-to-study-in-canada/

Mok, K. H. (2012). Cooperation and competition in tango: Transnationalization of higher education and the emergence of regulatory regionalism in Asia. In J. Hawkins, K. Mok, \& D. Neubauer (Eds.), Higher education regionalization in Asia Pacific: Implications for governance, citizenship and university transformation (pp. 137-160). Palgrave Macmillan.

Morgan, J. (2016, June 16). Can India and China dominate HE in the 21st century? Times Higher Education. https://www.timeshighereducation.com/ features/can-india-and-china-dominate-higher-education-in-the-twenty-first-century

Newspapers Canada. (2016). Circulation report: Daily newspapers 2015. http://newspaperscanada.cal wp-content/uploads/2016/06/2015-Daily-Newspaper-Circulation-Report-REPORT FINAL.pdf

Nye, J. S. (1990). Soft power. Foreign Policy, 80 , 
153-171. https://doi.org/10.2307/1148580

Nye, J. S. (2008). Public diplomacy and soft power. The ANNALS of the American Academy of Political and Social Science, 616(1), 94-109. https://doi. org/10.1177/0002716207311699

Paikin, S. (2019, May 8). Why depending on international students is a double-edged sword for Ontario schools. TVO Opinion. https://www.tvo.org/article/ why-depending-on-international-students-is-a-double-edged-sword-for-ontario-schools\#: :tex$\mathrm{t}=$ Why\%20depending\%200n\%20international\%20 students $\% 20$ is $\% 20 \mathrm{a} \% 20$ double-edged,students $\% 20$ are\%20picking\%20up\%200ur\%20government\%E2\%80\%99s\%20financial\%20slack

Palamar, S., \& Jardine, E. (2012). Does Canada need a new Asia policy? Canadian Foreign Policy Journal, 18(3), 251-263. https://doi.org/10.1080/11926422.2 $\underline{012.741050}$

Peterson, P. M. (2014). Diplomacy and education: A changing global landscape. International Higher Education, 75, 2-3. https://doi.org/10.6017/ ihe.2014.75.5410

Quan, D. (2019a, August 13). 'Significant and clear' threat: What Canada's spy chief says about China behind closed doors. National Post. https://nationalpost.com/news/canada/significant-and-clear-threatwhat-canadas-spy-chief-says-about-china-behindclosed-doors

Quan, D. (2019b, November 07). Meng Wanzhou arrest caused UBC leaders concern over enrolment, fundraising, internal documents show. National Post. https://nationalpost.com/news/meng-wanzhou-arrest-caused-ubc-leaders-concern-over-enrolment-fundraising-internal-documents-show

Sá, C., \& Sabzalieva, E. (2018). Scientific nationalism in a globalizing world. In B. Cantwell, H. Coates, \& R. King (eEs.), Handbook on the politics of higher education (pp. 130-148). Edward Elgar Publishing.

Saraisky, N. (2015). Analyzing public discourse: Using media content analysis to understand the policy process. Current Issues in Comparative Education, 18(1), 26-41. https://eric.ed.gov/?id=EJ1095584

Seib, P. M. (2016). The future of diplomacy. Polity Press.
Shute, J. (1999). From here to there and back again: International outreach in the Canadian university. In S. L. Bond \& J. P. Lemasson (Eds.), A new world of knowledge: Canadian universities and globalization (pp. 21-44). International Development Research Centre. https://idl-bnc-idrc.dspacedirect.org/ bitstream/handle/10625/26271/IDL-26271.pdf?sequence $=1$

Silcoff, S. (2019, January 19). Canadian universities continuing R\&D funding partnerships with controversial telecom. The Globe and Mail. https://www. theglobeandmail.com/business/article-canadian-universities-continuing-rd-funding-partnerships-with/

Sinclair, J. (2017). Geopolitical policy challenges on a new Canadian path. Policy Options. https://policyoptions.irpp. org/magazines/may-2017/geopolitical-policy-challenges-on-a-new-canadian-path/

Stack, M. (2007). Representing school success and failure: Media coverage of international tests. Policy Futures in Education, 5(1), 100-110. https://doi. org/10.2304/pfie.2007.5.1.100

Stein, S., \& Andreotti, V. (2015). Cash, competition, or charity: International students and the global imaginary. Higher Education, 72(2), 225-239. https://doi. org/10.1007/s10734-015-9949-8

Suspitsyna, T. (2015). Cultural hierarchies in the discursive representations of China in the Chronicle of Higher Education. Critical Studies in Education, 56(1), 21-37. https://doi.org/10.1080/17508487.201 $\underline{5.971330}$

Suspitsyna, T., \& Shalka, T. R (2019). The Chinese international student as a (post)colonial other: An analysis of cultural representations of a US media discourse. The Review of Higher Education, 42, 287-308. https://doi.org/10.1353/rhe.2019.0053

Trilokekar, R. (2010). International education as soft power? The contributions and challenges of Canadian foreign policy to the internationalization of higher education. Higher Education, 59(2), 131-147. https://doi.org/10.1007/s10734-009-9240-y

Trilokekar, R. D. (2015, February). From soft power to economic diplomacy? A comparison of the changing rationales and roles of the U.S. and Canadian 
federal governments in international education. Center for Studies in Higher Education (CSHE) University of California Berkeley: Research \& Occasional Paper Series. http://www.cshe.berkeley.edul sites/default/files/shared/publications/docs/ROPS. CSHE .2.15.DesaiTrilokekar.SoftPowerEconDeplomacy.2.9.2015.pdf

University Affairs. (2019, February 07). If Canada orders international students home, some Canadian schools face money trouble: Agency. Global News. https://globalnews.ca/news/4937419/canadian-universities-china-students-moodys/

Usher, A. (2018, August 29). Canada's growing reliance on international students. Policy Options. https:/l policyoptions.irpp. org/magazines/august-2018/canadas-growing-reliance-on-international-students/

Usher, A. (2020, May 20) The outlook for international students. Higher Education Strategy Associates. https://higheredstrategy.com/the-outlook-for-international-students/

Vanderklippe, N. (2018a, October 30). China's military scientists target Canadian universities. The Globe and Mail. https://www.theglobeandmail.com/world/ article-chinas-military-scientists-target-canadian-universities/

Vanderklippe, N. (2018b, October 31). Foreign espionage of Canadian research a risk to 'national interests': CSIS: Service says it routinely meets with universities to warn them of the dangers, as Canada has become a target for Chinese intelligence-gathering. The Globe and Mail. http://ezproxy.library. yorku.ca/login?url=https://www-proquest-com. ezproxy.library.yorku.ca/docview/2127110158?

Vanderklippe, N. (2019, May 19). Canada-China dispute takes toll on business school. The Globe and Mail. https://www.theglobeandmail.com/ business/article-canada-china-tensions-beginning-to-take-a-toll-on-business-relations/

VTN News Network. (2019, November 14). Australia seeks to curb interference in universities. BBC News. https://www.bbc.com/news/world-australia-50418267

Wojciuk, A. (2018). Higher education as a soft power in international relations. In Y. Watanabe (Ed.), Handbook of cultural security (pp. 343-360). Edward Elgar Publication.

Wong, A. (2019, February 7). Moody's Investors Services warns big risk to Canadian schools if China pulls students. The Globe and Mail. https://www. theglobeandmail.com/canada/article-moodys-investors-services-warns-big-risk-to-canadian-schools-ifchinal

Xu, X., \& Friesen, J. (2019, February 18). Incidents on Canadian campuses prompt questions of Chinese state interference. The Globe and Mail. https:ll www-proquest-com.ezproxy.library.yorku.cal docview/2182377565

Yi, W. (2018, December 18). Huawei case casts shadow over Canada-bound students. Global Times. or

\section{Contact Information}

Roopa Desai Trilokekar

RDesaiTrilokekar@edu.yorku.ca 